\section{Fra akuttmedisin til rehabilitering}

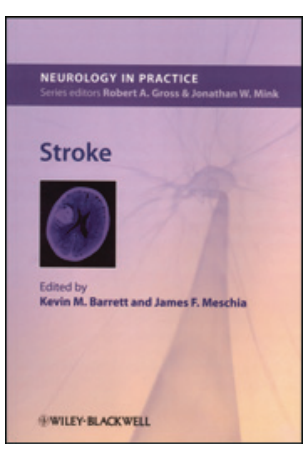

Kevin M. Barrett, James F. Meschia, red. Stroke

164 s, tab, ill. Chichester: Wiley-Blackwell, 2013. Pris GBP 52

ISBN 978-0-470-67436-9

Denne utgivelsen er en del av serien Nevrologi i praksis - med praktisk informasjon, mest i form av evidensbaserte fakta. Forfatterne er 16 anerkjente nevrologer og nevroradiologer fra USA og Canada.

Boken omhandler akutt slagbehandling, rådføring via telemedisin og rehabilitering, og den avsluttes med aktuelle kliniske skåringer til praktisk bruk etter pasientens ankomst på sykehuset, telemedisinsk kommunikasjon og videre dokumentasjon av forløpet. Den er oversiktlig og logisk oppbygd.

Første kapittel handler om klinisk diagnostisering av akutte fokale nevrologiske utfall og tidsrelasjon fra start av symptomene. Forfatterne gir råd om hvordan man unngår vanlige diagnostiske feil, og hvordan MR-teknologien har forandret TIA-definisjonen. I tillegg gjør forfatterne oppmerksom på den store differensialdiagnostiske utfordringen ved «stroke mimics». Under henvisning til den høye sikkerheten av intravenøs trombolyse anbefaler de at man bør gi behandlingen selv om man i akuttsituasjonen ikke helt kan utelukke at «stroke mimic» foreligger. Metoder utover intravenøs trombolyse er også kort nevnt og omfatter intraarteriell trombolyse, embolektomi og sonotrombolyse. Bruk av muligens mer effektive medikamenter som tenecteplase er kort nevnt i kapittel 3, hvor man henviser til videre aktuell forskning.

Forfatterne gir god veiledning, og gjennom sju kapitler tar de for seg de kliniske utfordringene legen møter fra pasientens ankomst i akuttmottak, over individuell nevroradiologisk og akuttmedisinske vurderinger til årsak, utredning, sekundær prevensjon, komplikasjoner og rehabilitering. Kapitlene inneholder også rammer med gode tips og råd, funn fra store, relevante studier og advarsler om mulige feil, i tillegg til oversiktlige tabeller, CT-, MR- og PETbilder. Hvert kapittel avsluttes med en kort referanseliste som gir anledning til fordypning i ønsket tema. Telemedisin er lite utbygd i Norge så langt og har dessverre ikke oppnådd stor relevans. Men ved de få sentrene som har denne funksjonen, vil leger i spesialisering få en meget god introduksjon før og ved bruk av denne verdifulle hjelpefunksjonen.

Boken kan ikke erstatte lærebøker i nevrologi, nevroradiologi, indremedisin og rehabilitering. Men det er høy kvalitet på informasjonen som gis på de 158 sidene, og leser man fra første til siste kapittel, får man en komprimert oppdatering om behandling av hjerneslag i sykehus.

Jeg anbefaler boken sterkt som innføring i arbeidet med slagpasienter for kolleger i spesialisering i nevrologi, indremedisin, rehabilitering og geriatri, og for andre fagpersoner med interesse for best mulig behandling av hjerneslag.

Ulrike Waje-Andreassen

Nevrologisk avdeling

Haukeland universitetssykehus

\section{Nyttig om kommunikasjon med syke barn}

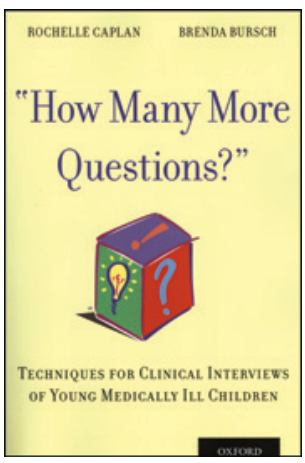

Rochelle Caplan, Brenda Bursch
How many more questions?

Techniques for clinical interviews of young medically ill children. 324 s, tab, ill. Oxford: Oxford University Press, 2013. Pris GBP 33

ISBN 978-0-19-984382-4

Dette er en bok som handler om strategier for å oppnå god kommunikasjon med syke barn i alderen 5-10 år. Målgruppen er ulike faggrupper som jobber med syke barn, og inkluderer barneleger, barnepsykiatere og psykologer, i tillegg til sykepleiere, fysioterapeuter og sosionomer.

Hovedintensjonen er å gi den som intervjuer, innsikt i barns aldersavhengige tenkemåte. Forfatterne presenterer en praktisk tilnærming til samtaler med barn.

I første del gir de en innføring i barns aldersavhengige forståelse for begreper som skiller seg vesentlig fra voksnes tenkemåte. For eksempel er barn konkrete og ikke abstrakte i sin tenkemåte, og de har begrenset tidsforståelse - noe som voksne ofte ikke reflekterer over når de stiller spørsmål og får svar fra barn. Leseren presenteres for 12 retningslinjer som fremmer innhenting av barns egne opplevelser av det som plager dem. I de neste kapitlene tar forfatterne for seg praktisk bruk av samtaleteknikker for barn med ulike tilstander som angst, sinne, atferdsvansker og somatiseringslidelser, for å nevne noen. Et kapittel på 60 sider er viet barn med epilepsi som en modell for en biopsykososial tilnærming.

I den siste delen gir forfatterne råd om hvordan man skal gå frem under spesielt utfordrende samtaler, for eksempel i samtaler med traumatiserte barn og barn som skal dø.

Boken er tettpakket med tekst over vel 300 sider, og illustrasjonene er ikke spesielt gode, men kapitlene er didaktisk oppbygd med rikt siterte fakta om tilstandene, kliniske samtaleeksempler og oppsummerende avsnitt til slutt. Har man lest innledningskapitlet, kan man få mye ut av bare å lese enkeltkapitler. Kunnskap om barns kommunikative utviklingsnivå er en forutsetning for å få til en god anamnese av barna, og boken er et kjærkomment bidrag til økt forståelse av barns tenkemåte under samtaler.

Jeg anbefaler boken spesielt for barneleger og barnepsykiatere/ psykologer, men annet helsepersonell som jobber og intervjuer syke barn, vil også kunne ha god nytte av den.

\section{Trine Tangeraas}

Barnemedisinsk avdeling

Oslo universitetssykehus, Rikshospitalet 